УДК: 343.951

https://doi.org/10.52058/2786-4952 -2021-4(4)-341-352

Вітомський Юрій Леонідович кандидат психологічних наук, член Національної психологічної асоціації, доцент кафедри кримінального права, процесу і криміналістики, Київський інститут інтелектуальної власності та права Національного університету «Одеська юридична академія», Харківське Шосе, 210, м. Київ, 02000, тел.: (068) 884-88-44, e-mail: u.vitomskyi@gmail.com, https://orcid.org/0000-0003-3094-5104

Бондаренко Степан Юрійович старший методист кафедри кримінального права, процесу i криміналістики, студент 3 курсу, Київський інститут інтелектуальної власності та права Національного університету «Одеська юридична академія», Харківське Шосе, 210, Київ, 02000, тел.: (095) 551-26-12, e-mail: bondarenko.stephan@ukr.net, https://orcid.org/0000-0001-8328-5117

\title{
ВИНА ЯК ПРОЯВ СУСПІЛЬНИХ ВІДНОСИН У СТРУКТУРІ ПСИХОЛОГІЇ ДЕВІАНТНОЇ ПОВЕДІНКИ ЧЕРЕЗ ПРИЗМУ ПРОБЛЕМАТИКИ ЮРИДИЧНОЇ ПСИХОЛОГІї
}

Анотація. У статті розглядається поняття вини як суспільних відносин 3 метою глибшого проникнення у його сутнісну основу, з'ясування закономірностей виникнення, розвитку та функціонування цього соціальноправового явища.

Адже, як відомо, найважливішим елементом нормального існування будьякої соціальної системи $\epsilon$ порядок, який, у свою чергу, складається із встановлення та забезпечення виконання схвалюваних більшістю членів суспільства правил поведінки.

Сьогодні вже не викликає сумніву твердження, що люди не можуть бути абсолютно однаковими хоча б тому, що кожен з них має свій власний організм, і ці організми займають різні зони у просторі.

Отже, неминуче на всіх етапах розвитку та функціонування суспільства інтереси окремих індивідуумів постійно чи тимчасово перебувають у протиріччі iз загальноприйнятими нормами поведінки. У той момент, коли зіткнення колективних та індивідуальних інтересів набуває відкритого характеру, протистояння окремої особистості та суспільства загалом переростає у конфлікт, оскільки конфлікт (від латів. conflictus - зіткнення) $є$ не що інше, як граничний випадок загострення протиріччя.

Окрім цього, варто наголосити на тому, що психологічна теорія вини у кримінальному праві переживає досить помітну кризу. Багато іiі положень, сформовані у першій половині XIX ст. і прийняті згодом як догма, суперечать 
Журнал«Герспективитаінновації науки»

(Серія «Гедагогіка», Серія «Гиихологія», Серія «Медицин»

№4(4) 2021

правозастосовчій практиці, а також сучасним результатам психології та когнітивних наук.

До того ж, аналіз показує, що феномен вини по-різному розглядається в юридичній та психологічній науці. За Ч. Рікфорт (2001), юридична вина - це питання, що не стосується почуттів. Людина є юридично винною, якщо вона порушила закон, абсолютно незважаючи на те, чи відчуває вона почуття провини з приводу скоєного чи ні. У психології ж, навпаки, акцент робиться на почуття провини. Однак ця розбіжність щодо змісту поняття провини не єдина. Аналіз кримінально-правової літератури та норм КК України, і навіть коментар до них показав, що є розбіжність у розумінні провини між традиційним визначенням $\mathrm{i}$ точкою зору сучасних авторів-юристів, які прагнуть використовувати нові психологічні знання.

Тому, окрім поставленої мети, вважаємо, що настійно потрібен перегляд застарілих основ психологічної теорії вини.

Ключові слова: психологія, юридична психологія, вина, девіантна поведінка, почуття провини, переживання вини, психологічна теорія вини.

Vytomski Yuriy Leonidovich $\mathrm{PhD}$ in Psychology, member of the National Psychological Association, Associate Professor of the Department of Criminal Law, Procedure and Criminalistics, Kyiv Institute of Intellectual Property and Law, National University "Odessa Law Academy", Kharkiv Shose, 210, Kiev, 02000, tel.: (068) 884-88-44, e-mail: u.vitomskyi@gmail.com, https://orcid.org/0000-0003-3094-5104

Bondarenko Stepan Yuriyovich Senior methodologist of chair of criminal law, procedure and criminality, student of 3 course, Kyiv Institute of Intellectual Property and Law, National University "Odessa Law Academy", Kharkivske Shose, 210, Kyiv, 02000, tel.: (095) 551-26-12, e-mail: bondarenko.stephan@ukr.net, https://orcid.org/0000-0001-8328-5117

\section{GUILT AS A MANIFESTATION OF SOCIAL RELATIONS IN THE PSYCHOLOGY OF DEVIANT BEHAVIOUR THROUGH THE PRISM OF LEGAL PSYCHOLOGY ISSUES}

Abstract. This article examines the concept of guilt as a social relations with the aim of penetrating deeply into its essence, understanding the patterns of origin, development and functioning of this social and legal phenomenon.

Indeed, as you know, the most important element in the normal existence of any social system is the order, which, in turn, is composed of the establishment and enforcement of rules of conduct accepted by most members of society.

Today it is no longer controversial to say that people cannot be exactly the same, at least because each of them has their own body, and these bodies occupy different areas of space. 
So, inevitably, at all stages of society's development and functioning, the interests of individual individuals are constantly or temporarily at odds with universally accepted norms of behaviour. At the moment when the clash of collective and individual interests becomes open, the opposition of an individual and the society as a whole grows into a conflict, since a conflict (from the Latin. Conflict is nothing else but a borderline case of aggravation of confrontation.

Apart from that, it should be noted that the psychological theory of guilt in criminal law is experiencing a rather remarkable crisis. Many of its provisions, formulated in the first half of the 19th century and accepted later as dogma, contradict law enforcement practice as well as the current results of psychology and the cognitive sciences.

Moreover, the analysis shows that the phenomenon of guilt is viewed differently in legal and psychological science. According to C. Ricfort (2001), legal guilt is a matter that does not concern feelings.

A person is legally guilty if she has violated the law, irrespective of whether she feels guilty about the crime or not.

In psychology, however, the emphasis is on the feeling of guilt. However, this difference in the meaning of guilt is not the only one.

An analysis of criminal and legal literature and the $\mathrm{CC}$ of Ukraine, and even a commentary to them showed that there is a difference in the understanding of guilt between the traditional definition and the point of view of contemporary lawyers, who seek to use new psychological knowledge.

Therefore, apart from the stated goal, we believe that a review of the outdated foundations of the psychological theory of guilt is urgently needed.

Keywords: Psychology, legal psychology, guilt, deviant behaviour, feelings of guilt, experience of guilt, psychological theory of guilt.

Постановка проблеми. У практиці кримінального судочинства трапляються випадки засудження за заподіяння шкідливих наслідків без вини, нерідко також відбувається неправильна кваліфікація дії через помилковий висновок про форму вини чи неправильної оцінки мотивів і цілей злочину (кримінального правопорушення), а часом призначається покарання, яке не відповідає ступеню вини правопорушника.

Питома вага подібних помилок досягає 40-50\% у загальній масі судових помилок [1]. Так, наприклад, у кримінальному праві вина в теоретичному плані розглядається у кількох аспектах, кожен з яких висвічує певну межу цього поняття.

Психологічний аспект розкриває суть провини. Юристи виділяють інтелектуальний та вольовий моменти провини. У цьому користуються такими психологічними поняттями, як свідомість, передбачення наслідків, бажання наступу.

Кримінально-правовий аспект підкреслює та обставина, що поняття наміру та необережності використовуються лише стосовно злочинів (кримінальних правопорушень) [3]. 
Журнал«Герспектвиитаіноовації наукиљ

(Серія«Гедагогіка», Серія«Гцихологія», Серія«Медицинв»

№4(4) 2021

Предметний аспект провини тісно пов'язаний із кримінально-правовим. Він означає, що провини як абстрактного поняття немає, вона має пов'язуватися зі скоєнням конкретної дії (або бездіяльності). Особа визнається не взагалі винною, а винною у скоєнні, наприклад, крадіжки, хуліганства чи іншого якогось конкретного злочину (кримінального правопорушення).

Тільки у такому предметному розгляді провини зменшується ризик винесення неправосудного вироку за думки і переконання, і навіть діяння, хоча об'єктивно вони і пов'язані з злочином, але скоєні за відсутності провини.

Соціальний аспект провини означає, що особа, вчиняючи злочин (кримінальне правопорушення), зазіхає найважливіші соціально-політичні цінності, що в Україні з урахуванням Конституції і тому $\epsilon$ охоронювані кримінальним законом.

3 урахуванням усіх названих аспектів А. В. Наумов (1996) дає таке визначення: «Вина - це психічне ставлення особи до конкретного суспільно небезпечного діяння, що вчиняється, і до його суспільно небезпечних наслідків, виражене у формі наміру або необережності, в якому проявляється антисоціальність діяльності винного, яка засуджується судом від імені народу» [2].

Вважаємо, що цю думку можна віднести до традиційної, зазначивши у своїй, що поняття «ставлення», використовуване у визначенні, занадто ємне, щоб конкретизувати визначення провини.

Аналіз уявлень про вину у юридичній психології показав, що немає про неї чіткого цілісного уявлення [5]. Відрізняються поняття провини та винності. Можливо, тому виникають протиріччя у виділенні форм провини та їх складових між традиційним та сучасним поданням серед фахівців із кримінального права. Автори монографій та підручників, у тому числі підручників 3 юридичної психології, визначають вину більше у юридичному аспекті. Оскільки мало психологічних робіт, присвячених вивченню винного діяння, юристам складно дати раду його психологічному змісту.

В цілому проблема полягає в наступному: з одного боку, в кримінальноправовому аспекті в традиційному розумінні провини виділяють 2 критерії провини: інтелектуальний (свідомість винним суспільно небезпечного характеру діяння, його наслідків), вольовий (бажання, свідоме припущення шкідливих наслідків). На основі поєднання цих критеріїв виділяють форми провини (намір, необережність), тим самим визначають кваліфікацію злочину.

3 іншого боку, багато авторів вважають розподіл ознак провини на інтелектуальний та вольовий моменти фіктивними та неспроможними. На їхню думку, створюється ілюзія того, що інтелект задіяний лише за усвідомлення та передбачення, а за бажання - відсутній. Звідси законодавчі формулювання не дають можливості провести кордон між формами провини.

Аналіз останніх досліджень i публікацій. Варто сказати, що в теоретичному руслі кримінального права існує протиріччя щодо форм вини. У 
зв'язку з цим виникає труднощі правильної кваліфікації винного діяння - умисел (прямий, непрямий) або необережність (самовпевненність, недбалість) [4]. Крім того, наголошується на складності, яка пов'язана з неясністю психологічного механізму винного діяння, яка випливає з того, що в психології одні дослідники провину розглядають як емоцію (Р. Осьюбел, К. Уокслер, Д. Мауер та ін.), інші здатність до переживання провини — як особистісну рису (Ж. Мошер, З. Окл, Еге. Олівер), але загалом винне діяння у психології не описано $[6,7,8]$.

Аналіз психолого-юридичної літератури показав, що юристи та юридичні психологи розглядають механізм злочинної поведінки, що характеризується як психосоціальний. Однак узагальнена модель, якою вони користуються, не $\epsilon$ цілісною, що описує функціонування психіки фрагментарно.

Новизна нижчеописаного авторського підходу полягає у розгляді винного діяння цілісно, через модель психічної організації, що проявляється як суб'єктне самоврядування. Новими результатами нашого дослідження стали дані про те, що при скоєнні винного діяння у формі наміру людина сама здатна відбудувати роботу 13 ланок психічної організації. Винне діяння у формі необережності, на відміну умислу, відповідає неефективному суб'єктному самоврядуванню.

Мета статті - розглянути поняття вини як суспільних відносин з метою глибшого проникнення у його сутнісну основу, з'ясувати закономірності виникнення, розвитку та функціонування цього соціально-правового явища.

Виклад основного матеріалу. Конфлікт — явище універсальне тому, що властивий усім без винятку громадським системам, усім соціальним рівням.

Панівне становище у вітчизняній науці кримінального права займає так званий психологічний підхід у розумінні вини, в рамках якого розвиваються психологічна, оцінна (нормативна) та психологооцінна концепції вини.

Найчастіше під виною розуміється певне психологічне/психічне (інтелектуальне та вольове) ставлення суб'єкта до вчинюваного діяння та його наслідків. У цьому у різних концепціях вини по-різному трактуються «внутрішня» i «зовнішня» оцінки дії суб'єкта, набувають різні форми суб'єктивно-об'єктивного змісту винної поведінки.

Нинішнє поняття провини в українській кримінально-правовій науці $\epsilon$ результатом складної взаємодії релігійних, філософських, моральних, наукових i повсякденних уявлень, що склалися в XVIII-XIX ст [10].

Не вдаючись до подробиць детермінації конфлікту, слід зазначити, що основною посилкою тут $є$ поняття нерівності. Відомий західний соціолог Р. Дарендорф сформулював чотири іпостасі нерівності [12].

Нерівність походить 3 природного (біологічного) розмаїття схильностей, характерів, інтересів людей та соціальних груп; 3 природної (інтелектуальної) відмінності талантів, здібностей, обдарувань; із соціальної диференціації (по горизонталі) принципово рівноцінних позицій; iз соціального розшарування (по вертикалі відповідно до престижу, багатства i соціокультурного тла), що виявивилося в ієрархії соціального статусу. 
Журнал«Герспектвиитаіноовації наукиљ

(Серія«Гедагогіка», Серія«Гцихологія», Серія«Медицинв»

№4(4) 2021

Споруджені цими причинами протиріччя неминуче викликають протест із боку окремих осіб [3]. Різновиди подібного протесту дуже різноманітні, але найнебезпечнішою формою його зовнішнього прояву є злочин (кримінальне правопорушення).

Розглядаючи злочин (кримінальне правопорушення) крізь призму зіткнення антагоністичних протиріч суспільства та окремої особистості, не можна не помітити, що всі протиборчі сторони в кінцевому підсумку представлені людьми, отже, йдеться про соціальний конфлікт. «Соціальний конфлікт - це явний чи прихований стан протиборства об'єктивно розбіжних інтересів, цілей та тенденцій розвитку соціальних суб'єктів, пряме чи опосередковане зіткнення соціальних сил на грунті протидії існуючому суспільному порядку, особлива форма історичного руху до нової соціальної єдності» [4].

Продовжуючи просуватися від загального до приватного, слід зазначити, що злочинний протест особистості вимагає розгляду не в абстрактному соціальному просторі, а в реальному зв'язку 3 діючими правовими інструментами і структурами, тобто має правову природу і тому може бути названий юридичним конфліктом.

Для того щоб відмежувати злочин від всіх інших різновидів юридичних конфліктів (трудових, шлюбно-сімейних, цивільних, адміністративних тощо) та підкреслити його індивідуальність, визначимо цей вид зіткнення протилежних інтересів як кримінальний конфлікт.

Варто зауважити, що кримінальний конфлікт - явище динамічне, що розвивається, що дозволяє при більш детальному аналізі виділити кілька стадій розвитку. На першій стадії, яку можна назвати латентною, виникає суперечність між інтересом окремої особистості та інтересом, що охороняється кримінальним законом. Деякі вчені позначають цей момент як «деформацію потреб та інтересів» [5]. На наступній стадії правові відносини, що виникли між учасниками конфлікту, отримують нове якісне вираження, оскільки на захист законного інтересу, що зазнав злочинного посягання, постають правоохоронні органи. Так звана процесуальна стадія може бути дуже тривалою i, як правило, включає попереднє розслідування того, що сталося, передання обвинуваченого суду, судовий розгляд справи, касаційне провадження і т.д. [6]. Ця стадія завершується прийняттям юридичного рішення (складання відмовного матеріалу, припинення кримінальної справи, винесення обвинувального чи виправдувального вироку).

Таким чином, основною особливістю кримінального конфлікту $\epsilon$ та обставина, що будь-який злочин по суті складається 3 двох соціальних конфліктів: злочинця 3 потерпілим (безпосередньо чи опосередковано) та злочинця з правоохоронними органами (протікає в рамках процесуальних дій сторін).

Одна 3 функцій кримінального законодавства - витіснення 3 життя суспільства конфліктних відносин, що породжуються фактами скоєння злочинів. 
Тому, на нашу думку, спосіб вирішення конфлікту між особою, яка вчинила злочин, і суспільством слід розглядати як кримінальну відповідальність, а засобом дозволу - кримінальне покарання.

Багато відомих мислителів минулого неодноразово говорили про те, що конфлікт знаходиться всередині людини і що саме людина є головним носієм конфлікту. Наприклад, Еге Шостром, описуючи внутрішній стан людини, наголошував, що «у кожному з нас закладена така двопартійна система, за якої одна частина - при владі; інша - в лояльній опозиції» [8]. Кожна особистість являє собою стійку систему соціально значимих характеристик, обумовлених існуючою системою суспільних відносин, культурою та біологічними особливостями індивіда. При цьому в однієї особи можуть існувати декілька взаємовиключних потреб, цілей, цінностей, інтересів. Усі вони соціально обумовлені, навіть якщо носять суто біологічний характер, оскільки задоволення пов'язані з цілої системою певних соціальних відносин [17].

Своєрідність індивідуальної злочинної поведінки полягає в тому, що поряд із факторами зовнішнього середовища, до яких належать причини та умови, його також обумовлюють і внутрішні фактори [16]. Більш того, фактори зовнішнього середовища стають спонукаючими силами поведінки, лише переломившись у свідомості особистості.

Загальновідомо, що кримінально-правовий вплив здатний досягати своїх цілей лише у разі його застосування до осіб, які мають актуальну або потенційну можливість усвідомлювати характер та наслідки вчинених ними діянь.

Вітчизняне кримінальне право переважно стоїть на позиції, що центральне місце у понятті вини належить психічному відношенню людини до вчинюваної iii суспільно небезпечного діяння, вираженому в формі умислу чи необережності $[11,12]$.

Психіка $є$ властивість живих високоорганізованих матеріальних тіл, яке полягає в їх здатності відображати своїми станами навколишню їхню незалежність від них існуючу дійсність. Психічні явища - відчуття, уявлення, поняття - суть більш менш точні і глибокі відображення, образи, знімки дійсності [13].

У психології всі психічні явища прийнято поділяти на три основні категорії: 1) психічні процеси - динамічне відображення дійсності в різних формах (відчуття, сприйняття, пам'ять, мислення тощо); 2) психічні стани - відносно стійкі рівні психічної діяльності, які виявляються в підвищеній або зниженій активності особистості (бадьорість, втома, активність, пасивність, дратівливість, настрій тощо); 3) психічні властивості особистості - стійкі утворення, які забезпечують певний якісно-кількісний рівень психічної діяльності та поведінки, типовий для індивіда (аполегливість, організованість, дисциплінованість та інші) $[14$, с. $72 ; 15]$.

Названі категорії, що представляють різні сторони психічного життя особистості, так чи інакше виявляють себе у конкретному злочині. Будь-яке злочинне діяння можна розглядати як психічний процес, що розгортається у часі, 
має початок і поклала край. Цей процес, як правило, протікає на тлі певного психічного стану суб'єкта, який нерідко відіграє дуже важливу роль. I нарешті, в злочині виражаються певні психічні властивості особистості [16, с. 32].

Вихідне визначення психічного, що дається 3 позицій діалектикоматеріалістичного монізму, має на увазі, 3 одного боку, функцію високоорганізованої матерії, 3 іншого боку - відображення об'єктивної дійсності. Іншими словами, психічне завжди має двояку форму існування: 1) об'єктивна - виявляється у житті та діяльності; 2) суб'єктивна - це рефлексія, інтроспекція, самосвідомість, відображення психічного в самому собі.

У психології накопичені численні дані, що показують багатовимірність, різнопорядковість потенційного психічного, яке виступає таким завжди лише стосовно «дійсного», «актуального» [17, с.17]. Під потенційним зазвичай розуміються такі властивості, можливості особистості, які можуть здійснитися i стати реальністю тільки за певних умов. Під актуальним розуміють вже розвинені та діючі в тих або інших умовах властивості та особливості особистості, що є реалізацією та конкретизацією тих властивостей, які раніше перебували в латентному, потенційному стані.

Потенційне не $є$ щось приховане, ніяк не $є$ тим, що не виявляє себе. Навпаки, воно проявляється, але тільки епізодично, у нестійких і мінливих формах. Реальним проявником наявних потенційних можливостей виступають актуальні взаємодії особистості із дійсністю. Наприклад, «нестійкий» тип злочинця, під яким у кримінології розуміють як такий, що вчинив злочин вперше, але допускав i раніше різні правопорушення та аморальні прояви. Найбільш поширеними представниками цього типу $\epsilon$ правопорушники, які в нетверезому стані дрібні крадіжки, хуліганство, рідше - пограбування, розбої, деякі насильницькі злочини. При суттєвій зміні життєвих обставин на краще та ефективному виховному впливі вони здатні утриматися від протиправних дій.

Ще одним прикладом прояву потенційного психічного є, як на нашу думку, порушення кримінального закону так званими «ситуативними» злочинцями. Злочини скоюються ними тому, що ситуації мають вирішальне значення. Справа в тому, що через особливості своєї психіки вони потрапляють у жорстку залежність від ситуації i не знаходять соціально прийнятного способу іï вирішення. До «ситуативних» належить чимало насильницьких злочинців, а також осіб, які вчинили корисливі злочини у суб'єктивно складних життєвих обставинах, наприклад, при матеріальних труднощах.

Матеріали психології наочно демонструють, що реальність, будучи якісно відмінною від можливості, в той же час постає як подальший розвиток можливості, як їі розгортання у новій системі відносин.

Весь життєвий шлях конкретної особистості - це, певною мірою, конкретизація діалектики можливого та дійсного. Перехід потенційного в актуальне (можливого в дійсне) - найважливіший момент психічного розвитку, але в сучасній психології досліджено, скоріше, лише умови, а не механізми цього переходу. 
До цих умов відносять: 1) накопичення та інтеграцію різнопорядкових можливостей особистості; 2) виникнення ситуації, що висуває підвищені вимоги до суб'єкта; 3) значне загострення протиріч у життєвих відносинах людини. Усі ці умови виступають лише передумовами перетворення можливого у дійсне, фундаментальною ж основою та активним його початком, на думку психологів, виступає сам суб'єкт, який має самовизначитися по відношенню до свого можливого та власними зусиллями звести можливе до ступеня провідних детермінантів свого життя, тобто - перетворити у дійсне.

Ефективність реалізації кримінальної відповідальності багато в чому залежить від правильного визначення наявності та ступеня суб'єктивного зв'язку між вчинюваним діянням та особою (особами), що його здійснили. Беручи до уваги зазначений вище соціальний характер будь-якого злочинного діяння, такий зв'язок може бути представлений у вигляді суспільних відносин.

«Зв'язок» та «ставлення» здавна є предметом філософського дослідження. Як в минулому, так і в сучасному ці поняття співіснують в тих самих наукових текстах, використовуються як синоніми. Однак більшість дослідників вважають, що поняття «ставлення» ширше за поняття «зв'язок». Ставлення охоплює не лише як зв'язку між явищами дійсності, а й їх ізольованість, роздільність; не лише як їх залежність друг від друга, а й відому незалежність, відносну самостійність $[16,17,18]$.

У філософії термін «ставлення» означає момент взаємозв'язку багатьох видів сущого, що мають суб'єктивну чи об'єктивну, абстрактну чи конкретну форму. Цим словом називають матеріальну чи смислову єдність, взаємовизначуваність різних існувань [15]. Ставлення не є безпосереднім виразом певних процесів, воно завжди вказує на особливу взаємозалежність окремих складових чи кінцевих результатів даних процесів, виступає опосередкованим зв'язком взаємодіючих або протиборчих об'єктів.

Хоча правознавці активно говорять про використання психологічного підходу у трактуванні вини, вони чомусь не використовують наукові досягнення, отримані психологією та когнітивними науками за останні десятиліття $[13$, с. 11]. Слід погодитися 3 думкою О.Д. Ситковськох, згідно 3 якою для фахівців із кримінального права характерна позиція (правильніше назвати іiі ілюзією) самостійного, без участі психологів, розкриття змісту низки основних понять та інститутів кримінального права, які фактично вимагають психологічного аналізу [14].

Доречно навіть говорити про відокремлення кримінально-правової науки від сучасної психології, внаслідок чого складається така парадоксальна ситуація: правознавці говорять про використання психологічного підходу, тоді як сучасні досягнення психології свідчать про їхню суперечність нинішнім кримінальноправовим трактуванням вини. Виходить, що «гіпноз старих формул» (М.А. Чельцов-Бебутов), що поширений у кримінальному праві, виявляється сильнішим із наукових здобутків психології. Наприклад, у кримінальному праві 
Журнал«Герспективита інновації науки

(Серія«Гедагогіка», Серія «Гиихологія», Серія«Медицинв»

№4(4) 2021

традиційно досліджуються лише інтелектуальний та вольовий компоненти змісту вини, тоді як емоційний компонент провини [11, с. 25] зазвичай недооцінюється.

Визнання суб'єктом злочину порушення ним кримінального закону не $є$ рівнозначним переживанням цією особою вини (почуття провини) за вчинений ним злочин. Як слушно зазначають Е.В. Матвєєва та Є.А. Дровосекова, серед злочинців є багато тих, хто, усвідомлюючи свої дії як тяжкий вчинок, при цьому не відчуває провини та каяття [16].

Зміст (та визначення) вини у кримінально-правовому аспекті має відрізнятися від підходів інших наук, зокрема і психології. Однак наскільки обгрунтованим у сучасному кримінальному праві $є$ використання згаданого про «психологічний підхід», що має минущий історичний характер, у трактуванні провини, якщо знання сучасної психології ігноруються наукою кримінального права? Виходить, що у нинішньому «психологічному підході» у кримінальному праві психологічним є тільки саме це слово, оскільки сучасні здобутки цієї науки не використовуються. Наприклад, так зване «психологічне» визначення вини у вітчизняному кримінальному праві не грунтується на сучасній психології вини, якщо не сказати, що між ними взагалі прірва в їхньому смисловому навантаженні.

Зазначене протиріччя наполегливо вимагає свого вирішення.

Як справедливо зазначається у літературі, «завдання юридичної науки полягає не в тому, щоб не помічати суперечності, що виникають між нормативно закріпленими правилами поведінки та тією соціальною дійсністю, для врегулювання якої i створюються ці правила, а в тому, щоб дати цим протиріччям розгорнуту правову характеристику та намітити конкретні заходи щодо їх усунення» [7, с. 37]. Лауреат Нобелівської премії Д. Канеман та його послідовники стверджують, що люди переважно ірраціональні і схильні до когнітивних спотворень [13, 19]. Професор-нейролінгвіст Т. Чернігівська зазначає, що «мозок приймає рішення за 30 секунд до того, як людина це рішення усвідомлює. 30 секунд - це величезний період часу для мозкової діяльності.

То хто ж у результаті приймає рішення: людина або його мозок? Про це ми 3 прагнемо поговорити у наступних дослідженнях.

Висновки. Таким чином, будучи самостійним феноменом, вина вивчається різними областями знання, що розглядають іiі з різних сторін. Однак настійно потрібні сучасні кримінально-правові (доктринальні), психологічні тлумачення вини та винності, що розкривають їх кримінально-правову сутність та враховують актуальну соціальну дійсність, яка за останні десятиліття зазнала кардинальних змін.

Викладене свідчить про те, що вітчизняна кримінально-правова наука має значну роботу з подальшого вдосконалення інституту вини, а успішне вирішення цього питання неможливе без використання наукових досягнень сучасної психологічної науки, а також без проведення критичних кримінально-правових 
досліджень, спрямованих на подолання обмеженості юридичного розуміння діяльності та пов'язаних із встановленням вини.

Таким чином, особа в момент скоєння злочину (кримінального правопорушення) може мати психічне відношення до діяння, а може і не мати його. Що ж до ставлення суспільства до цього діяння, що передбачає, насамперед, моральну та правову оцінку суспільно небезпечних дій (бездіяльності) та суспільно небезпечних наслідків, то ця складова вини $\epsilon$ завжди. Отже, саме це ставлення, яке відповідно до сторін, що беруть у ньому участь є суспільними відносинами, і складає сутнісну основу вини.

Ставлення суспільства до особи, яка вчинила злочин, з упевненістю можна назвати правовим, оскільки його суб'єкти мають суб'єктивні правові та юридичні обов'язки. Суб'єктами цих правовідносин, з одного боку, як правило, виступають співробітники правоохоронних органів як повноважні представники інтересів суспільства та окремих його членів, з іншого - особи, які вчинили суспільно небезпечні посягання на цінності, що охороняються кримінальним законом. Об'єктом правовідносини є порушене право чи інтерес. Суб'єктивні права мають на увазі можливість негативної оцінки поведінки особи, що вчинила суспільно небезпечне діяння.

Юридичні обов'язки, у свою чергу, означають необхідність дати суспільству звіт у своїх небезпечних діях (бездіяльності) та нести за них відповідальність.

Правильне визначення сутності вини, на наш погляд, має найважливіше теоретичне значення з'ясування закономірностей виникнення, розвитку та функціонування цього соціально-правового явища. Без сутності неможливо точно визначити зміст, форми та правила встановлення вини, i, нарешті, визначення сутності вини сприятиме зміцненню законності нашій країні.

\section{Лimepamypa:}

1. Дюркгейм Э. Норма и патология // Социология преступности: (Современные буржуазные теории): сб. статей. М., 1966. С.42.

2. Философская энциклопедия. / гл. ред. Ф.В. Константинов. М.,1964. Т.3. С.55.

3. Dahrendorf R. Class and Conflict in an Inductrial Society. Stanford (California),1959. P.157-165.

4. Запрудский Ю.Г. Социальный конфликт. Ростов, 1992. С.54.

5. Кудрявцев В.Н. Правовое поведение: норма и патология. М., 1982. С.160-167.

6. S. Bondarenko (2021). Determination of corruption in the judicial system of Ukraine: psychological and political genesis. V International Scientific Congress Society of Ambient Intelligence 2021 (ISC-SAI 2021) have been published by OKTAN PRINT (The publication is assigned with a DOI number:https://doi.org/10.46489/CPIS-070421) Praha, Czech Republic [in English].

7. Марцев А.И. Общие вопросы учения о преступлении. Омск, 2000. С.50-51.

8. Шостром Э. Анти-Карнеги, или человекманипулятор / пер. с англ. Минск, 1992. С.73.

9. Козырев Г.И. Конфликтология. Внутриличностные конфликты // Социальногуманитарные знания. 1999. № 2. С.102-103.

10. Петелин Б.Я. Психология правонарушения: учебное пособие. М., 1974. С.5

11. Прохоров В.С. Преступление и ответственность. Л., 1984. С.70-77.

12. Хорнабуджели Б.В. Психологическая сторона вины. Тбилиси, 1981. С.82. 
13. Зелинский А.Ф. Осознаваемое и неосознаваемое в преступном поведении. Харьков, 1986. С.69.

14. Флетчер Дж., Наумов А.В. Основные концепции современного уголовного права. M., 1998. C.244.

15. Рарог А.И. Общая теория вины в уголовном праве. М., 1980. С.21

16. Четверикова И.В. Роль семьи, профессиональной карьеры и пола подсудимых при вынесении приговоров российскими судьями // Обвинение и оправдание в постсоветской уголовной юстиции: сб. ст. / под ред. В.В. Волкова. М., 2015.

17. Loginov N. Cognitive distortions: why we are wrong [Electronic resource]. URL: https://postnauka.ru/faq/89948 (date of reference: 09.11.2021).

18. Vitomski, Y., \& Bondarenko, S. (2021). THEORETICAL AND PRACTICAL FOUNDATIONS FOR INNOVATIVE IMPLEMENTATION OF PSYCHOTHERAPEUTIC CONFRONTATIONAL SUPERVISION: TOWARDS A CONCEPT OF COGNITIVE PSYCHOTHERAPY IN HIGHER EDUCATION INSTITUTIONS. Public Administration and Law Review, (3), 65-71. https://doi.org/10.36690/2674-5216-2021-3-65

\section{References:}

1. Durkheim E (1966) Norma i patologia. Sociology of Crime: (Modern Bourgeois Theories): Collection of Articles. Moscov, Russia [in Russian]

2. F.V.Konstantinov (1964) Philosophical Encyclopedia, Moscov, Russia [in Russian]

3. Dahrendorf R. (1959) Class and Conflict in an Inductrial Society. Stanford (California), [in English]

4. Zaprudsky Y.G. (1992) Sotsialnyiy konflikt. Rostov, Russia [in Russian].

5. Kudryavtsev V.N. (1982) Provovoe povedeniye: norma i patologiya. Moscov, Russia [in Russian]

6. S. Bondarenko (2021). Determination of corruption in the judicial system of Ukraine: psychological and political genesis. V International Scientific Congress Society of Ambient Intelligence 2021 (ISC-SAI 2021) have been published by OKTAN PRINT (The publication is assigned with a DOI number:https://doi.org/10.46489/CPIS-070421) Praha, Czech Republic [in English].

7. Martsev A.I. (2000) Obschie voprosyi ucheniya o prestuplenii. Omsk, Russia [in Russian]

8. Shostrom E. (1992) Anti-Karnegi, ili chelovek-manipulyator. Minsk, Belarus [in Russian]

9. Kozyirev G.I. (1999) Konfliktologiya. Vnutrilichnostnyie konfliktyi I Sotsialnogumanitarnyie znaniya. Omsk, Russia [in Russian]

10. Petelin B.Ya. (1974) Psihologiya pravonarusheniya: uchebnoe posobie. Moscov, Russia [in Russian]

11. Prohorov V.S. (1984) Prestuplenie i otvetstvennost. Lviv, Ukraine [in Ukraine].

12. Hornabudzheli B.V. (1982) Psihologicheskaya storona vinyi. Tbilisi, Georgia [in Rissian].

13. Zelinskiy A.F. (1986) Osoznavaemoe i neosoznavaemoe v prestupnom povedenii. Harkov, Ukraine [in Ukraine].

14. Fletcher Dzh., Naumov A.V. (1998) Osnovnyie kontseptsii sovremennogo ugolovnogo prava. Moscov, Russia [in Russian]

15. Rarog A.I. (1980) Obschaya teoriya vinyi v ugolovnom prave. Moscov, Russia [in Russian]

16. Chetverikova I.V. (2015) Rol semi, professionalnoy kareryi i pola podsudimyih pri vyinesenii prigovorov rossiyskimi sudyami // Accusation and acquittal in post-Soviet criminal justice: coll. of papers. London, England [in English]

17. Loginov N. (2018) Cognitive distortions: why we are wrong [Electronic resource]. URL: https://postnauka.ru/faq/89948 (date of reference: 09.11.2021). London, England [in English]

18. Vitomski, Y., \& Bondarenko, S. (2021). THEORETICAL AND PRACTICAL FOUNDATIONS FOR INNOVATIVE IMPLEMENTATION OF PSYCHOTHERAPEUTIC CONFRONTATIONAL SUPERVISION: TOWARDS A CONCEPT OF COGNITIVE PSYCHOTHERAPY IN HIGHER EDUCATION INSTITUTIONS. Public Administration and Law Review, (3), 65-71. https://doi.org/10.36690/2674-5216-2021-3-65. Tallin, Estonia [in English]. 